
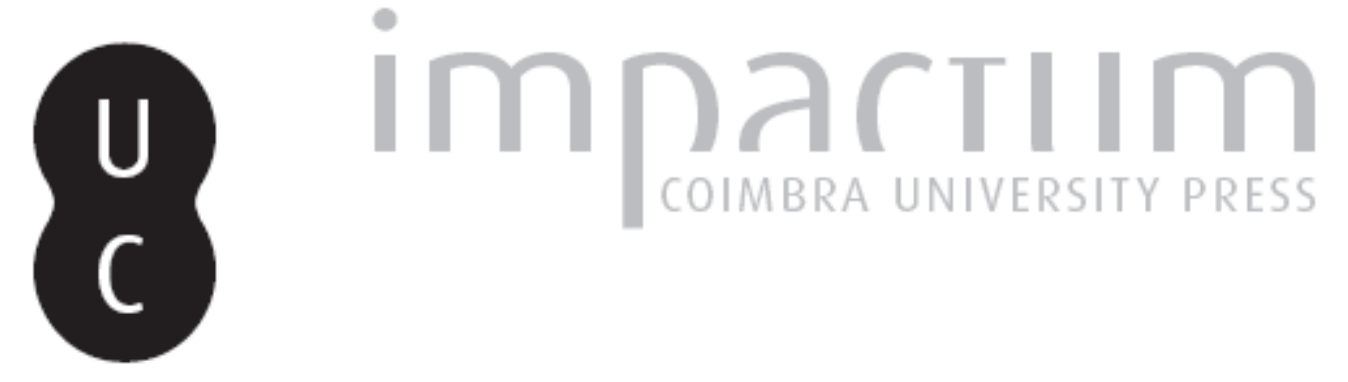

\title{
Beati mortui qui in Domino moriuntur: atitudes perante a morte e locais de sepultura dos irmãos franciscanos seculares da cidade de Coimbra (1707-1785)
}

Autor(es): $\quad$ Silva, Ana Margarida Dias da

Publicado por: Imprensa da Universidade de Coimbra

URL persistente:

URI:http://hdl.handle.net/10316.2/40960

DOI:

DOI:https://doi.org/10.14195/1645-2259_16_10

Accessed : $\quad$ 26-Apr-2023 11:05:31

A navegação consulta e descarregamento dos títulos inseridos nas Bibliotecas Digitais UC Digitalis, UC Pombalina e UC Impactum, pressupõem a aceitação plena e sem reservas dos Termos e Condições de Uso destas Bibliotecas Digitais, disponíveis em https://digitalis.uc.pt/pt-pt/termos.

Conforme exposto nos referidos Termos e Condições de Uso, o descarregamento de títulos de acesso restrito requer uma licença válida de autorização devendo o utilizador aceder ao(s) documento(s) a partir de um endereço de IP da instituição detentora da supramencionada licença.

Ao utilizador é apenas permitido o descarregamento para uso pessoal, pelo que o emprego do(s) título(s) descarregado(s) para outro fim, designadamente comercial, carece de autorização do respetivo autor ou editor da obra.

Na medida em que todas as obras da UC Digitalis se encontram protegidas pelo Código do Direito de Autor e Direitos Conexos e demais legislação aplicável, toda a cópia, parcial ou total, deste documento, nos casos em que é legalmente admitida, deverá conter ou fazer-se acompanhar por este aviso.

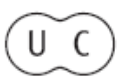




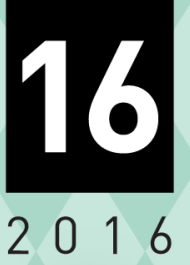

\section{Revista \\ de História \\ da Sociedade \\ e da \\ Cultura}




\title{
Beati mortui qui in Domino moriuntur. Atitudes perante a morte e locais de sepultura dos irmãos franciscanos seculares da cidade de Coimbra (1707-1785)
}

\author{
Beati mortui qui in Domino moriuntur. Attitudes \\ towards death and burial sites of secular Franciscan \\ brothers in the city of Coimbra (1707-1785)
}

\author{
Ana Margarida Dias da Silva \\ Venerável Ordem Terceira da Penitência de S. Francisco \\ Universidade de Coimbra - CHSC \\ margaridadiasdasilva@gmail.com
}

Texto recebido em / Text submitted on: 03.04.2016

Texto aprovado em / Text approved on: 14.06.2016

Resumo: A Venerável Ordem Terceira da Penitência de S. Francisco de Coimbra garantia aos seus membros benefícios espirituais e materiais, incluindo o acompanhamento dos irmãos à sepultura e os sufrágios por alma dos irmãos falecidos. Os estatutos e memórias da fraternidade permitem compreender a atitude dos terceiros franciscanos seculares perante a morte e quais as obrigações e direitos dos membros da Ordem Terceira de Coimbra. Nos 1653 registos de óbitos da Ordem Terceira conimbricense, entre 1707 e 1785 , colhe-se informação sobre o local de sepultura dos irmãos franciscanos seculares de Coimbra, objetivo do presente trabalho. As igrejas colegiadas de Santiago e de S. Bartolomeu, as igrejas de Santa Justa, de S. Pedro e de S. João de Almedina, o mosteiro de Santa Cruz, e os conventos de S. Domingos e de S. Francisco da Ponte congregam o maior número de enterramentos dos irmãos franciscanos seculares no século XVIII.

Palavras-chave: Ordem Franciscana secular, sufrágios, enterramentos, petições de esmolas, morte.

Abstract: The Venerable Third Order of Penance of St. Francis of Coimbra guarantees spiritual and material benefits to its members, including the brothers escort to the grave and the suffrages for the deceased brothers' souls. The statutes and fraternity memories allow us to understand the secular Franciscan brothers' behaviour towards death and what its members' obligations and rights were. In the 1653 death records of the Third Order of Coimbra, between 1707 and 1785 we gather information on the secular Franciscan brothers' burial places, which is the goal of this study. The collegiate churches of Santiago and S. Bartolomeu, the churches of Santa Justa, S. Pedro and S. João de Almedina, the monastery of Santa Cruz, and the convents of S. Domingos and S. Francisco da Ponte congregate the largest number of secular Franciscan brothers' burials in the eighteenth century.

Keywords: secular Franciscan Order, suffrages, burials, alms petitions, death. 


\section{Introdução}

Antes das preocupações higienistas com a saúde pública do século XIX, da contestação aos enterramentos nas igrejas e da lei de 21 de setembro de 1835, que ordenava a construção de cemitérios públicos, os enterramentos realizavam-se "no centro dos povoados (a igreja e o seu adro)" funcionando "como garante simbólico da salvação colectiva no final dos tempos" (Catroga 1993: 595). Nesse âmbito, "as irmandades e Ordens Terceiras propiciavam aos seus associados a garantia de inumação, acompanhamento e sufrágios necessários para uma boa morte. As garantias proporcionadas por estas agremiações minimizavam o temor da morte e da perdição da alma no outro mundo, constituindo-se em importantes atrativos para a população" (Moraes 2009: 282).

Numa época em que a salvação da alma era parte essencial da vivência religiosa, "A presença dos mortos no mundo dos vivos ganhou muito terreno ao longo da idade moderna, afirmando-se fortemente a partir do século XVII" (Araújo 2010: 102), período de crescimento das ordens terceiras seculares, a que não fica alheio o facto de proporcionarem o acompanhamento dos irmãos à sepultura, a celebração dos sufrágios pelos seculares falecidos e a atribuição de esmolas aos irmãos pobres para realização dos funerais ${ }^{1}$.

A "Igreja, depositária de uma teoria coerente sobre a salvação, hegemoniza o discurso sobre a morte e interpela os crentes no quotidiano, através da palavra e da imagem" (Araújo 1995: 1) e a divulgação da crença no Purgatório e o "crescente apelo dos vivos em favor dos mortos traduzido na celebração de sufrágios" (Gouveia 2000: 587) encontraram "particular empenho de carmelitas, franciscanos, jesuítas, dominicanos, agostinhos, e das constituições dos bispados que as tornavam obrigatórias, pondo a tónica nas orações e sufrágios de missas e ofícios pelos defuntos" (Gouveia 2000: 589).

As práticas tradicionais de enterramento nas igrejas, sustentadas pela crença religiosa de que "alcançariam a glória das almas aqueles cujos corpos jazessem em companhia de imagens dos santos, dentro dos templos sagrados" (Catroga 1993: 596) e o acompanhamento religioso e a consequente administração dos últimos sacramentos inscrevem-se como mensagem dominante neste quadro (Araújo 1995: 14).

\footnotetext{
Entre outros benefícios espirituais e materiais como a atribuição de esmolas aos irmãos caídos em pobreza, a assistência aos irmãos enfermos e idosos (com a criação de hospitais e asilos, mas também com a visita domiciliária aos irmãos doentes), ou o ensino das primeiras letras aos filhos dos irmãos pobres, ações desenvolvidas, por exemplo, pela Venerável Ordem Terceira da Penitência de S. Francisco de Coimbra entre os séculos XVII e XX, e de que é herdeiro, hoje, o Lar da instituição.
} 
Neste trabalho procura-se compreender as atitudes dos irmãos franciscanos seculares de Coimbra em relação à morte: a norma ditada pelos estatutos, os sufrágios realizados e as esmolas distribuídas, sendo que esta última forma de assistência se destinava aos irmãos pobres. É também objetivo identificar os locais de sepultura dos irmãos franciscanos seculares conimbricenses, associados à "densa malha paroquial e conventual" (Araújo 1995: 2). A hierarquia do lugar de enterramento no solo sagrado da igreja é reveladora da posição social e económica do defunto e a recolha dos locais de inumação pode ser um contributo mais para o conhecimento da mole humana que compunha a instituição.

A Venerável Ordem Terceira da Penitência de S. Francisco de Coimbra, fundada a 5 de janeiro de 1659 como pessoa moral canonicamente ereta, no convento de S. Francisco da Ponte, não descurou nenhuma destas funções e manteve vivo registo da sua ação no campo da assistência espiritual e material relacionada com a morte e a salvação das almas dos irmãos seculares falecidos.

Utilizaram-se como fontes os Estatutos (1660), as Memórias (1661) e a Determinação a respeito de se favorecerem os irmãos pobres na vida e na morte (1709) para o enquadramento daquilo que é a projetada ação da ordem terceira sobre a relação dos franciscanos seculares com a morte, as Petições de esmolas (1707-1785) de forma a localizar o auxílio material concedido pela Ordem Terceira em caso de pobreza e relacionado com a morte, mas principalmente os livros de óbitos existentes no Arquivo da Venerável Ordem Terceira da Penitência de S. Francisco de Coimbra. A Memória dos irmãos que faleceram neste ano de 1707 e pelos quais se celebrou na forma do Estatuto desta Venerável Ordem Terceira, e os dois livros de óbitos que lhe sucedem, permitiram colher informações preciosas e precisas sobre o local de enterramento das irmãs e dos irmãos seculares falecidos (Silva 2013: 67-68).

Estabeleceram-se, como balizas cronológicas, a data do primeiro assento de óbito existente no arquivo da Venerável Ordem Terceira de S. Francisco, 1707, e 1785, ano em que a Ordem Terceira de Coimbra deixou a sua capela da Ponte e passou a reunir na igreja colegiada de S. Cristóvão.

\section{A morte nos Estatutos}

Para compreender a atitude dos franciscanos seculares perante a morte é necessário recorrer às Memórias e Estatutos da fraternidade, instrumentos que, a par dos compromissos, "baseiam na obrigação de entreajuda na morte, assis- 
tência aos irmãos doentes, sepultura, cumprimento de obséquios fúnebres e demais sufrágios para salvação dos confrades falecidos" (Araújo 1995: 43).

Nos Estatutos da Ordem Terceira de S. Francisco de Coimbra, de 1660, no seu $9^{\circ}$ capítulo, diz-se:

E por que em tudo nos queremos ajustar com o que manda a Regra e os summos pontífices, detreminamos por ser assi neçessario, que ninhum irmão falte com o vintem de cada mes, pellos muitos gastos que faz a Mesa, assi com os diffunctos, por cada hum dos quais mandará dizer sincoenta missas em altar privilegiado, tanto que morrerem ... (Estatutos 1660:4).

A importância da missa para a salvação das almas surge associada à ideia de Purgatório, local intermédio, estada temporária dos defuntos antes de alcançar o Céu. De facto, "a crença no Purgatório incentivou os homens a ingressarem nestas instituições, muito particularmente nas associações que cuidavam da salvação. Lucrava-se em vida com a pertença a um corpo com identidade e prestígio, mas sobretudo na morte, através de celebrações de imploração colectiva pela salvação dos defuntos, promovidas por estas instituições" (Araújo 2010: 102), onde se incluem as ordens terceiras.

Rezar pelos irmãos defuntos constituía-se como um acto de caridade, num gesto de compaixão pelos que já haviam partido, fundados na crença da interseção e interferência dos vivos junto das almas dos mortos. Numa época em que "As preocupações com a salvação das almas eram imensas e todos aguardavam a solidariedade de todos para mais facilmente alcançarem a felicidade eterna" (Araújo 2004: 59), as ordens terceiras seculares eram mais um garante da observância destes preceitos, fosse através dos sufrágios gerais, fosse pelo cumprimento de legados.

No entanto, no ano 1661 eram muitas as dúvidas relativamente às 50 missas $^{2}$ que se mandavam dizer pelos irmãos terceiros que faleciam, segundo estava determinado no capítulo $9^{\circ}$ dos Estatutos e lançado, igualmente, no livro das Entradas e profissões de irmãos. Assim, em Mesa de 16 de janeiro do

2 Por exemplo, na Ordem Terceira de S. Francisco de Vila Viçosa "A assistência espiritual estava garantida com a celebração de uma missa por cada irmão sacerdote e 50 salmos por cada irmão leigo" (ARAÚJO 2004: 59). Em 1676, a Ordem Terceira de Braga manda ampliar a "quantidade de celebrações de três para cinco missas demonstra o desejo de oferecer aos seus associados maiores "bens de salvação". Primordial para atrair novos irmãos e ampliar a visibilidade do sodalício, acrescentar missas aos sufrágios mostrava-se crucial nos primeiros anos de sua existência. Esta atitude demonstra também capacidade financeira por parte da instituição." (MORAES 2009: 281). Segundo a mesma autora, em 1751 os irmãos terceiros da cidade do Porto recebiam 70 missas enquanto os do Rio de Janeiro, em 1745, celebravam-se 40 missas após a morte de algum membro e os terceiros paulistanos tinham direito 25 missas pela sua alma (MORAES 2009: 284-285). 
dito ano "sendo prezente o senhor Ministro o Doutor João de Azevedo, e o Reverendo padre commissario Frei Manuel da Columna; e os mais irmaos abaixo assinados... se dispoz e fez assento na maneira seguinte”. Segundo o Regimento da Venerável Ordem Terceira, no capítulo 13, cada irmão que tomar hábito está obrigado "de dar em cada hum mez hum vintém de esmola para os doentes e outras couzas de gastos da Ordem” e considerando frei Jerónimo da Cruz, o primeiro padre comissário da Venerável Ordem Terceira desta cidade de Coimbra, do convento de S. Francisco da Ponte, que as

dittas esmolas do vintém cada mez serem grandes, nos Estatutos que tirou a nossa Regra e fez lançar no principio do dito livro, pera bom governo da Ordem $<20$ réis 50 missas> confirmados pelo reverendo provincial frei Manoel da Esperança em os sinco de Fevereiro de $660 \mathrm{fez}$ Estatuto de se mandarem dizer pella alma de cada hum irmão $3^{\circ}$ que faleçer sincoenta missas em altar privilegiado de esmola cada huma a meyo tostão para que as Almas dos irmãos 3os que falecessem gosassem destes sufrágios poes em vida comprirão com as obrigaçoens de darem as esmolas que erão obrigados na forma da Regra (Memórias 1661: 1v-2).

Segundo o dito Estatuto era dada pena de expulsão a todo aquele que não pagasse nem quisesse "estar pello dito Estatuto como a quem não trata do bem comum da Ordem: com tudo ajustandonos com a nossa Regra no cap. [90] em que nos encommenda que quando ouvermos de reçeber alguns serviços se tire primeiro informação se tem posses e bens de que vivão". Fundada na caridade do seráfico S. Francisco, a ordem terceira de Coimbra não fechava as portas "a nenhum fiel christão que desejando salvarse e buscando este meyo da religião não seja aceito nella por não ser possoidor de bens temporaes pera poder satisfazer as ditas esmolas" (Memórias 1661: 1).

Assim, ficaram determinadas em 10 pontos as condições de celebração dos sufrágios.

Primeiramente, que todo o irmão terceiro que falecer antes de concluir o ano de noviciado, "constando que satisfez a suas obrigaçoens, assi espirit [u] aes, assistindo nos jubelleos e mais exerçiçios da Ordem e satisfez nos mezes de noviço que viveo a esmola dos vinténs", terá direito somente a cinco missas em altar privilegiado e será acompanhado pelos irmãos terceiros à sepultura

no simiterio que se assignalou de fronte da nossa capella quando essa fosse sua ultima vontade, com declaração (porem) que em o lugar em que for sepultado se não porá pedra algua com letreiro nem sem elle que diga quem ali jaz salvo hua só pedra e campa que haverá assignalada com letreiro em que se ajão de sepultar os comissários e ministros da dita Ordem (Memórias 1661:2). 
Neste primeiro ponto estabelecia-se, desde logo, uma diferença hierárquica visto que sepultura com epitáfio estava reservada exclusivamente para os padres comissários e ministros.

No ponto $2^{\circ}$ regista-se que todo o irmão terceiro que, embora tenha concluído o ano de noviciado, não peça para fazer a profissão, nem tenha satisfeito as esmolas dos vinténs, se passado o tempo de reflexão e preparação "sem acodirem às suas obrigaçoens não avendo justa cauza que os escuze”, então,

a este tal se lhe não farão sufrágios alguns de missas nem será acompanhado nem enterrado em o nosso semiterio poes foi visto não querer ser filho de nosso seraphico padre $S$. Francisco porque o anno de noviciado se dá pera que hum noviço se delibere se quer ou não quer professar (Memórias 1661: 2).

Contudo, havendo justa causa ou constando dos róis que pagaram os vinténs nalguns meses, caberá à Mesa votar "as missas que se lhe hão de dizer, avendo respeito às esmolas que tem dado e seu corpo será acompanhado na forma que se custuma por charidade" (Memórias 1661: 2).

Em terceiro lugar, estipulou-se que os irmãos professos que após a profissão esquecerem as suas obrigações de terceiros, tanto de assistência dos exercícios espirituais como das esmolas dos vinténs

a estes taes se lhe não dirão missas alguas e só por charidade será seu corpo acompanhado pelos irmãos 3os na forma que se costuma; os quais lhe emcommendarão sua alma a Deus, e se lhe rezará hum responso sobre a sepultura mas querendosse vir enterrar ao convento de $S$. Francisco da ponte não será enterrado dentro no cemiterio dos irmãos 3os mas no corpo da igreja (Memórias 1661: 2v).

Também este ponto estabelece uma diferença de tratamento entre os cumpridores e os que não cumpriram com as suas obrigações.

O $4^{\circ}$ ponto estipula que, no caso de um casal de irmãos terceiros professos, "dando somente por ambos hum < vintém> cada mez de esmola", aquele que falecer primeiro terá direito, apenas, a 25 missas; pelo que morrer depois, continuando a dar a esmola do vintém cada mês, serão ditas as 50 missas costumadas. E da mesma forma se rezarão apenas 25 missas relativamente a qualquer pessoa que dê apenas 10 réis de esmola mensais

excepto aquellas com quem a Meza avendo respeito a sua pobreza e por serviços pessoais que tenha feito a esta Ordem dispensar com ella em parte da esmola ou em todo porque a estes taes (fazendo pera <isso> primeiro petição à Meza) se dirão as sincoenta missas constando outrosi que satisfizerão as mais obrigaçoens da Regra (Memórias 1661: 2v). 
$\mathrm{O}$ ponto $5^{\circ}$ estabelece que qualquer irmão terceiro professo que falecer e que tenha cumprido com as suas obrigações, e até tenha deixado algumas esmolas, conforme se verifique nos róis dos anos antecedentes pelos secretários, "se lhe mandarão dizer as missas que parecer a respeito das esmolas que tem dado e serão acompanhados na forma que se costuma” (Memórias 1661: $2 \mathrm{v}-3$ ). No entanto, se se verificar que falhou algum pagamento do anual, apresenta-se declaração em como pagou sempre as esmolas dos vinténs, pois "nem por isso se deixarão de mandar dizer as sincoenta missas e somente se podem mandar pedir a seus herdeiros o que constar ficou devendo, e ou eles o dem ou não, sempre as sincoenta missas se dirão", por se considerar que "sempre tratou do bem comum da Ordem" e não deixou ano algum de pagar.

O $6^{\circ}$ parágrafo destes Estatutos foca-se nos irmãos terceiros beneméritos, ou aqueles que fizeram grandes esmolas à Ordem, e nos irmãos pobres, que serviram a Ordem com trabalho e assistência pessoal por muitos anos (como o andador geral ou os sacristães, por exemplo); a uns e a outros "ainda que nelles ouvesse alguns descuydos de pagarem as esmolas ... deve a Ordem gratificar em morte em lhes mandar dizer <as 50 missas> o trabalho e zelo com que servirão a dita Ordem e serão acompanhados e enterrados dentro no nosso semiterio". Acrescenta-se:

E para que de todo os irmãos 3os que desta cidade se absentarem com animo de a ella não tornarem a viver (excepto ministros e irmãos que derão boas e grandes esmolas pera a Ordem) e morrerem fora della não fiquem fora dos sufrágios que a dita Ordem manda fazer aos irmãos $3^{\text {os }}$ que derão algumas esmolas dos mezes que a dita Ordem se mandarão dizer pelo outavario dos Santos de cada hum anno dez missas neste convento de S. Francisco em altar privilegiado de que se dará de esmola por cada hua meyo tostão aplicadas todas pellos irmãos ${ }^{30 s}$ que forem falecidos antes que este estatuto se fizesse e depoes falecerem e juntamente pelos bemfeitores desta ordem defunctos (Memórias 1661: 3v).

O $7^{\circ}$ ponto determina a obrigação do padre comissário em alertar os noviços, quando lhes lançar o hábito, que se

"se obrigão a satisfazer as esmolas dos vintens dos mezes que a Regra manda: esta Meza e as que adiante forem lhes mandarão dizer pelas suas almas quando Padre Nosso Senhor for servido levalas para si os sufrágios, missas e mais obrigaçoens que costumão mandar fazer aos irmãos $3^{\text {os }}$ que satisfazem com o que são obrigados e que de outra maneira se lhe não mandarão dizer nem fazer” (Memórias 1661: 3v). 
A preocupação com a garantia do pagamento das esmolas por parte da ordem era grande, e fundamental para quem pagava pois "a esmola apagava o pecado tal como a água apaga o fogo” (Sá \& Lopes 2008: 12), por isso, para além da advertência feita aos noviços, a inquietação maior era com "alguas pessoas assi homens como molheres já de muita idade e pouco prestimo pera a Ordem fazem suas petiçoens pera serem admitidas nella", como fica registado no parágrafo número 8; a estes se deve acautelar "que sendo aseitos darão de intrançia boa esmola pera que quando falecerem tenhão dado esmola suficiente pera os emcargos das sincoenta missas"; caso contrário só seriam ditas as missas correspondentes aos meses de esmola pagos. Na verdade, as ordens terceiras seculares

de uma maneira ou de outra, todas dificultavam a entrada de fiéis com mais de 40 ou 50 anos, orientação comum às demais irmandades e destinada a travar custos cobertos mas não amortizáveis de enterro, acompanhamento e sufrágios (Araújo 1995: 21).

A penúltima observação relaciona-se com a missa dos segundos domingos, rezada pelo padre comissário, em que

terá a Meza obrigação mandar pagar a esmola della que será meyo tostão cada hua, aplicadas por todos os irmãos que vivos forem porque o reverendo senhor dê sua graça pera que o sirvão e a nossa Venerável Ordem $3^{a}$ (Memórias 1661: 4).

Por fim, no $10^{\circ}$ ponto, estipula-se que, em caso de dúvida sobre a matéria dos sufrágios das missas que se mandam dizer pelas almas dos irmãos terceiros "que nestes estatutos não esteja exposto e declarado", tem voto de decisão a Mesa assim como "em todos os cazos em que ouver duvida poderá dispor e mandar o que melhor for e convier para mayor bem e utilidade das almas dos irmãos 3os defunctos desta Venerável Ordem 3a”. A Ordem Terceira de Coimbra não acompanhava os irmãos que caíssem em pobreza e não pudessem pagar as esmolas anuais nem a esmola do acompanhamento da comunidade quando faleciam. Assim, em 1709, determinou-se que se fizesse um livro onde se anotassem os nomes de todos os irmãos ou irmãs que deixaram de ter possibilidades económicas de pagar as esmolas, sendo a Ordem obrigada a socorrê-los nas suas necessidades, onde se incluía a obrigação de lhes pagar o hábito e a esmola de acompanhamento da comunidade. Paralelamente, estipulou-se que, para além da inquirição de pureza de sangue, vida e costumes, se inquirisse também das possibilidades dos requerentes (Óbitos, 1707-1748: 1-2v). 
Era obrigação das confrarias e ordens terceiras garantir o acompanhamento dos irmãos na hora da morte e inumação e "ao delegar, em parte, nessas comunidades restritas os encargos de acompanhamento, enterro e resgate da alma, cada indivíduo participava, por sua livre iniciativa, no avolumar da pompa cerimonial. Esta vasta teia de solidariedades, justamente exibida no momento da morte, confirmava, face à sociedade, um estatuto de privilégio no acesso aos bens da salvação" (Araújo 1995: 4).

As misericórdias detinham o monopólio dos enterros por lei de 1593 "constituindo-se o aluguer do mobiliário fúnebre importante fonte de réditos" (Lopes 2010: 52).

Em 1745, e devido às contendas surgidas entre a Venerável Ordem Terceira de Coimbra e a Misericórdia da mesma cidade sobre a formalidade dos enterros dos irmãos terceiros conimbricenses e sobre quem levava a tumba da Misericórdia (Barrico 1895: 119-120), ficou determinado por

alvará porque Vossa Magestade he servido declarar que os irmãos terceyros da cidade de Coimbra podem usar de esquife proprio pera sepultarem de graca os seos Irmãos defuntos e que Mizericordia da dita cidade não tem direyto algum pera o impedir e que a escriptura celebrada entre a Mizericordia e os ditos Irmãos não pode prejudicar a estes em couza alguma como asima se declara (Estatutos, 1699-1853, 3-3v).

E esta foi uma contenda que diversas ordens terceiras tiveram com as misericórdias das suas localidades ${ }^{3}$. Em Coimbra, e "Nos termos do alvará de 14 de Fevereiro de 1617 Só a Misericórdia e a Universidade podiam ter «tumba de enterrar os mortos». Com este quase monopólio a Santa Casa garantia uma fonte de rendimentos com a qual podia custear os enterros dos pobres" (Lopes 2000: 119), mas por alvará de 4 de junho de 1745, a Ordem Terceira de S. Francisco de Coimbra passou a poder ter esquife próprio.

\section{Sufrágios por alma dos irmãos franciscanos seculares}

Se em 1661 se rezavam 50 missas pelas almas dos irmãos falecidos, nos registos de óbitos de 1720 fica-se a saber que

Semelhante contenda aconteceu entre e Ordem Terceira de Vila Viçosa e a misericórdia daquele lugar, sendo que a primeira ganhou o processo e o direito de sepultar os irmãos falecidos em esquife próprio, na segunda metade do século XVIII (Araújo 2004: 59). 
Mandey dizer as sobreditas missas pela Ordem seguinte: 31 por cada irmão ou irmã que paga annual de 240 e 15 missas pelo irmão ou irmã que paga annual de 120 segundo dispoem hum assento em que se fez redução de 50 missas em 31 e das 25 em 15 no termo dos assentos da Ordem fl. 5v (Óbitos 1707-1748: 43).

\section{O Livro de memórias da Nossa Venerável Ordem feito em 1774 inscreve no} título VIIIo Dos suffragios de que gozão os Irmãos desta Ordem a justificação que:

Não são iguais os suffragios em todos os irmãos que falecem porque como estes correspondem ao Anal [sic] que cada hum dos irmãos paga por anno como da diversidade nos anais a ha tambem nos suffragios, de forma que o que paga quatrocentos e oitenta tem quando falece sessenta e quatro missas, o que paga duzentos e quarenta tem trinta e duas missas, e o que paga de anal cento e vinte tem do suffragio pela sua alma desaseis missas (Memórias 1774-1888: 51v-52).

Reconhece-se, portanto, que o cumprimento da esmola anual determinava o número de missas a que a Ordem estava obrigada a rezar. Os valores estavam tabelados: 120 réis de anuais correspondiam a 16 missas, 240 réis de anuais davam direito a 32 missas e 480 réis de esmola anual garantiam 64 missas, como se verifica no caso do secretário da Universidade, Francisco Marques de Andrade, que faleceu a 14 de maio de 1766, e foi sepultado no colégio de S. Bento em caixão: teve 32 missas, "além de um ofício de honras que se fez na nossa capela por ser benfeitor da nossa Ordem e mais missas que se lhe mandaram dizer", ou seja, mais $32^{4}$.

Quanto aos devedores, eram descontadas as missas na proporção exata do valor em débito. Maria Teresa, viúva, devia 3 anos de anuais a 240 réis e, por isso, só foram rezadas 23 das 32 missas costumadas; o ourives José Rodrigues dos Santos, que devia 6 anos de anuais, pagos a 120 réis, só teve direito a 12 das 16 missas.

"Entretanto, os membros que não satisfaziam pontualmente as anuidades e outras contribuições exigidas não tinham direito às sepulturas e sufrágios” (Martins 2009: 388). E o cumprimento do pagamento dos anuais era escrutinado minuciosamente, como se verifica no registo abaixo:

4 Por exemplo, na Ordem Terceira de Vila Viçosa, no século XVII, era garantida a assistência espiritual com "a celebração de uma missa por cada irmão sacerdote e 50 Salmos por cada irmão leigo" quando morriam (Araújo 2004: 59); na Misericórdia de Lisboa, em 1618, "os estatutos determinavam que cada irmão rezasse 14 vezes o padre-nosso e igual número de ave-marias, enquanto a Santa Casa mandava celebrar, no dia seguinte ao enterro, um ofício de nove lições pela alma do defunto. Igual cerimónia era preparada para as mulheres dos confrades e viúvas que se mantivessem neste estado e para os filhos que tivessem entre 18 e 25 anos" (Araújo 2010: 104). 
Pareçeme que estão satisfeitas as missas pelas almas de todos os irmãos e irmans que neste anno faleceram o que milhor ha de constar do livro das sertidoens que não examinei por cauza de meu empedimento e me paresse senão disserão as missas pela alma do irmão Manoel Viegas o novo do suburbio de Sellas o que deve rezolver a Meza visto ficar devendo seissentos reis dos anais Coimbra de Mayo 20 de 1747. O secretário da ordem Bernardo Correia (Óbitos 1707-1748: 68).

Só após a deliberação da Mesa se daria cumprimento, ou não, aos sufrágios devidos por alma deste irmão falecido.

Como se verifica, questão premente e que perpassa pelos diversos escritos é o cumprimento do pagamento do anual, valor que garantia aos irmãos franciscanos seculares a assistência na velhice e/ou pobreza e, aquando do seu falecimento, a celebração de missas por sua alma. No livro dos Anuais de 1776-1780 está escrito na primeira folha: "Todo o irmão que dever de anuais quatro anos e daí para cima não se deve mandar avisar a Ordem para enterro sem pagar o que devem ...”. (Anuais 1776-1780: 1). É disso exemplo frei José de Jesus Maria, religioso de S. Domingos, que faleceu no dia 7 de agosto de 1770 "nas suas casas da Calçada", freguesia S. Bartolomeu e "dela foi de noute ao seu convento" e porque devia 1.390 réis de anuais, incumprimento correspondente a 11 anos e 7 meses de anuais não pagos a 120 réis "e por isso não teve missas podendo pagar".

Contudo aos irmãos que, "impossibilitados da sua pobreza, deixaram de satisfazer as esmolas costumadas" (Martins 2009: 388), a Ordem assegurava a celebração dos sufrágios e garantia o direito às sepulturas, como fica patente num registo escrito no final dos óbitos do ano 1741-42:

Parte dos irmãos acima e atrás declarados que faleceram se mandaram dizer as missas que lhe pertenciam excepto aos irmãos Pascoal Carvalho, Luísa da Fonseca e D. Escolástica Josefa Margarida de Nápoles Castelo Branco por estes estarem devendo de anuais muito mais do que importão as missas e por todos os mais se disseram as ditas missas como consta das certidões. Porpondo em Mesa a dúvida que tinha sobre não se ter satisfeito as missas dos irmãos Pascoal Carvalho, Luísa da Fonseca e D. Escolástica Margarida de Castelo Branco se resolveu na dita Mesa de 14 de maio de 1742 se mandassem dizer pela alma do irmão Pascoal Carvalho dezasseis missa se pela alma da irmã Luísa da Fonseca dezasseis missas e pela alma de nossa irmã D. Escolástica Margarida de Castelo Branco trinta e duas missas por constar serem todos pobres (Óbitos 1707-1748: 59-59v). 
Se inicialmente estes três irmãos foram considerados como devedores, logo se verificou, em Mesa, que faleceram em estado de pobreza, justificação bastante para que lhes fossem mandadas rezar as missas costumadas.

A obra de misericórdia dos "chamados «funerais por amor de Deus», os que eram feitos por caridade, gratuitamente, às famílias pobres que os requeriam" (Lopes 2000: 120) e que "eram desprovidos de aparato, mas não lhes faltava uma missa pela alma do falecido” (Araújo 2010: 106), era igualmente praticada pela ordem terceira conimbricense. Esta expressão só começa a surgir nos registos de 1765-1766, antes desta data, não há registo de qualquer outra expressão similar,: Marcelinho José Munhós foi levado no esquife da Ordem "pello amor de Deos dando se lhe habito e se pagou aos religiosos"; o sapateiro Tomás Francisco Tinoco faleceu no hospital e foi "sepultado pello amor de Deus" na igreja de Santiago; a José António Vieira deu-se "pello amor de Deuz habito, interro e missas"; o licenciado João Evangelista da Rocha faleceu no hospital a 26 de fevereiro em 1769 e "foi no esquife té igreja de Santiago" e se lhe pagou "abito acompanhamento dos religiosos e cova tudo pelo amor de Deus".

Ao lado da indicação dos "funerais por amor de Deus" surge a justificação do acto: "por ser pobre".

Aos irmãos pobres estava dada, então, a hipótese de requerer uma esmola para hábito, acompanhamento e sepultura como se explica no ponto seguinte.

\section{Petições de esmolas para hábito, acompanhamento e sepultura}

Em reunião na Casa do Despacho, aos 31 dias do mês de dezembro de 1709 ,

se propôs em a dita Meza que hera de menor piadade em esta nossa Ordem o não acompanhar os irmãos defuntos que cahião em pobreza e não tinhão com que pagar a esmola do habito e acompanhamento da comonidade (Óbitos 1707-1748: 1).

Decidiu-se, então, que, embora segundo os Estatutos da Ordem nenhum pretendente a entrar como irmão o fizesse sem a inquirição "pela qual conste tem oficio renda ou patrimonio de que viva e se possa sostentar honesta e honradamente sem andar pedindo" e que se não admitissem aqueles que não tinham capacidade de pagar as esmolas anuais, mas 
atendendo nos a caridade de que Nosso Sarafiço Patriarqua tanto nos emcomenda particularmente com os pobres $=$ emfermos $=$ e defuntos $(\ldots)$ haja nesta dita Ordem hum livro em o qual se assentem aquelles irmãos ou irmans que por desgraça dos tempos cahirão em pobreza e a estes não se lhes aseitara a Ordem as esmolas dos mezes mas como mais ser obrigada a secorelos em suas nassecidades e a darlhe em sua morte hum habito de burel deste Comvento que custa dez tostoiz e a pagar sinco testoiz por esmola do acompanhamento a comonidade (Óbitos 1707-1748: 1-1v),

exceto se forem irmãos de Nossa Senhora da Conceição pois nestes casos não lhes dará a dita Ordem mais que a mortalha, segundo o ajuste que se fez com o muito reverendo padre mestre frei António de S. Boaventura, guardião e padres discretos do convento de S. Francisco da Ponte

e pera este fim se dará parte logo que o irmão ou irmam faleser a nosso irmão andador geral pera que elle vinha buscar o habito e dar recado a comonidade notificando primeiro ao padre comissaroi e emformando se o irmão defunto he ou não da Conseyção (Óbitos 1707-1748: 1v-2).

Ressalva-se, no entanto, "que isto não he abrir portas aos gastos da Ordem mas so atender ao zello com que nos devemos haver com nossos irmãos pobres" e por isso obrigam-se os irmãos a fazer uma petição à Mesa, da qual conste o estado de pobreza a que chegaram, cuja veracidade será confirmada, e

mandamos que de hoje em diante assim como se manda tirar de suas possibilidades por que o nosso piadozo animo he so atender aos que pelo discurso do tempo cahirão em pobreza e não aquelles que actualmente sempre forão pobrez, por que estes segundo o estatuto forão mal aseitos e nestes termos não está a Ordem obrigada a remediar os erros passados nem a acodirlhes como filhos coando forão aseitos contra a disposição dos estatutos.

Nestes Estatutos fica bem patente que a função da Ordem Terceira de Coimbra era ajudar os irmãos que caíam em pobreza e não aqueles que já eram pobres pois se por um lado "as irmandades e ordens terceiras infundem a filosofia do pobre, por outro tomam severas precauções contra o assalto dos pobres. A pobreza é remida se advinda posteriormente, mas mal aceite como condição de ingresso" (Araújo 1995: 20). Para se ser admitido como irmão terceiro era imprescindível não ser indigente nem correr risco evidente de o ser, embora, naturalmente, as vicissitudes da vida pudessem empurrar alguns para isso. Inquiria-se "4. Se tem officio, renda, ou património de que viva, e se possa sustentar honestamente sem andar mendigando, ou se está 
tão falido de bens, e com tantos empenhos, que se receye chegue brevemente a mendigar, e se tem domicilio certo, ou se há vagabundo?” (Inquirições s. d.) As ordens terceiras impunham "critérios de selecção, o que as faziam instrumentos de reconhecimento social" (Lopes 2010: 110) e a exigência de uma profissão que fosse digna e dignificasse a Ordem, precavendo-se, logo à partida, quanto à possibilidade dos irmãos caírem em pobreza.

Ao analisarmos as petições de esmolas feitas pelos irmãos terceiros seculares entre $1721^{5}$ e 1785 , num total de 297 processos, chegamos facilmente à conclusão de que a quase totalidade dos requerentes solicita esmolas invocando motivos de pobreza.

A situação de pobreza em que se encontravam e a preocupação dos peticionários em garantir ajuda para sepultamento de familiares, pedidos de acompanhamento, hábito e mortalha, assim como de esquife, obrigaram-nos a recorrer a uma esmola.

Do total da série, apenas entre 1764 e 1774 se contabilizaram pedidos daqueles que, por falta de capacidade financeira, recorreram à Ordem Terceira de Coimbra para arcar com as despesas de: hábito e enterro (10), hábito e sepultura (8), hábito e acompanhamento (6), enterro (3), hábito, acompanhamento e sepultura (3), mortalha e sepultura (3), hábito (2), acompanhamento (1), acompanhamento no esquife (1), hábito de mortalha e enterro (1), mortalha (1), sepultura (1) e túnica para mortalha (1), num total de 41 petições que perfazem $12 \%$ do total. As esmolas foram pagas em dinheiro, como se vê na Tabela 1.

Tabela 1. Atribuição de esmolas em dinheiro (réis) para hábito, acompanhamento e enterro

\begin{tabular}{|l|c|l|}
\hline \multicolumn{1}{|c|}{ Pedido } & Esmola em dinheiro & \multicolumn{1}{|c|}{ Aplicação da esmola } \\
\hline saldar dívidas e para enterro & 800 rs & \\
\hline hábito e acompanhamento do irmão que faleceu & 1.500 rs & \\
\hline $\begin{array}{l}\text { hábito e acompanhamento do marido que } \\
\text { faleceu }\end{array}$ & 2.580 rs & \\
\hline hábito e acompanhamento & 1.500 rs & \\
\hline mortalha e sepultura & 1.500 rs & \\
\hline mortalha e sepultura & 1.500 rs & \\
\hline $\begin{array}{l}\text { hábito e acompanhamento para fazer o funeral } \\
\text { da mulher }\end{array}$ & 2.300 rs & $\begin{array}{l}1.500 \text { rs do hábito e acompanhamento; } 800 \text { rs da sepultura } \\
\text { na igreja de Santiago }\end{array}$ \\
\hline hábito, acompanhamento e sepultura & 1.000 rs & \\
\hline hábito, acompanhamento e sepultura & 2.550 rs & $\begin{array}{l}1.000 \text { rs do enterro, cova e hábito; } 500 \text { rs acompanhamento } \\
\text { dos religiosos; } 800 \text { rs cova na igreja de Santiago; } 200 \text { rs ao } \\
\text { coveiro; } 50 \text { rs de chamar o vigário com o esquife }\end{array}$ \\
\hline
\end{tabular}

5 A distribuição por anos não é uniforme não existindo processos nos anos 1722 a 1726, inclusive, 1728 a 1756 , inclusive, $1760,1775,1778,1782$ e 1785 , inclusive. 


\begin{tabular}{|c|c|c|}
\hline Pedido & Esmola em dinheiro & Aplicação da esmola \\
\hline túnica para mortalha & $1.500 \mathrm{rs}$ & $\begin{array}{l}1.000 \text { rs da túnica para mortalha e } 500 \text { rs do acompanha- } \\
\text { mento dos religiosos }\end{array}$ \\
\hline hábito, acompanhamento e sepultura & $1.000 \mathrm{rs}$ & \\
\hline mortalha e sepultura & $2.500 \mathrm{rs}$ & $\begin{array}{l}1.500 \text { rs do hábito e acompanhamento; } 800 \text { rs da sepultura na } \\
\text { igreja de Santiago; } 200 \text { rs ao coveiro }\end{array}$ \\
\hline hábito e acompanhamento & $1.500 \mathrm{rs}$ & \\
\hline hábito e enterro do marido & $1.500 \mathrm{rs}$ & \\
\hline hábito e enterro & $2.500 \mathrm{rs}$ & $\begin{array}{l}\text { hábito } 1000 \text { rs; acompanhamento dos religiosos } 500 \text { rs; cova } \\
800 \text { rs; coveiro } 200 \text { rs }\end{array}$ \\
\hline hábito e enterro do marido & $1.500 \mathrm{rs}$ & \\
\hline enterro da mulher & $2.500 \mathrm{rs}$ & $\begin{array}{l}\text { hábito } 1000 \text { rs; acompanhamento dos religiosos } 500 \text { rs; cova } \\
800 \text { rs; coveiro } 200 \text { rs }\end{array}$ \\
\hline hábito e enterro para o filho & $1.500 \mathrm{rs}$ & \\
\hline enterro do pai & $2.500 \mathrm{rs}$ & \\
\hline hábito e enterro do marido & $1.500 \mathrm{rs}$ & hábito $1000 \mathrm{rs}$; acompanhamento dos religiosos $500 \mathrm{rs}$ \\
\hline hábito & $2.400 \mathrm{rs}$ & $\begin{array}{l}\text { hábito e acompanhamento } 1.500 \text { rs; cova } 800 \text { rs; coveiro } \\
200 \text { rs }\end{array}$ \\
\hline hábito e enterro do marido & $1.000 \mathrm{rs}$ & $\begin{array}{l}\text { pagou só hábito por ser irmão da Irmandade de Nossa } \\
\text { Senhora da Conceição }\end{array}$ \\
\hline hábito e sepultura & $2.600 \mathrm{rs}$ & $\begin{array}{l}1000 \text { rs hábito; aos religiosos de S. Francisco } 500 \text { rs; cova em } \\
\text { S. Bartolomeu } 700 \text { rs; coveiro } 200 \text { rs; de sinais } 200 \text { rs }\end{array}$ \\
\hline hábito e enterro do marido & $3.500 \mathrm{rs}$ & hábito $2.500 \mathrm{rs}$ c cova na igreja de Santiago 800 rs; coveiro 200 rs \\
\hline hábito e enterro do marido & $2.000 \mathrm{rs}$ & \\
\hline hábito e enterro do marido & $2.100 \mathrm{rs}$ & $\begin{array}{l}\text { hábito } 1000 \text { rs; à comunidade de S. Francisco } 500 \text { rs; cova na } \\
\text { igreja } 400 \text { rs; coveiro } 200 \text { rs }\end{array}$ \\
\hline hábito e sepultura da mulher & $1.500 \mathrm{rs}$ & \\
\hline hábito e acompanhamento & $1.500 \mathrm{rs}$ & \\
\hline hábito e enterro do marido & $1.500 \mathrm{rs}$ & \\
\hline hábito e sepultura para sogra & 2.400 rs & $\begin{array}{l}\text { hábito } 1000 \text { rs; aos religiosos de acompanhamento } 500 \text { rs; } \\
\text { cova em S. Bartolomeu } 700 \text { rs; coveiro } 200 \text { rs }\end{array}$ \\
\hline hábito e sepultura para mãe & $1.900 \mathrm{rs}$ & hábito 1.000 rs; cova e coveiro 900 rs \\
\hline hábito e sepultura para mãe & $1.500 \mathrm{rs}$ & \\
\hline hábito e sepultura para irmã & 2.400 rs & $\begin{array}{l}\text { hábito } 1000 \text { rs; aos religiosos de acompanhamento } 500 \text { rs; } \\
\text { cova } 700 \text { rs; coveiro } 200 \text { rs }\end{array}$ \\
\hline hábito e sepultura para a filha & $2.500 \mathrm{rs}$ & $\begin{array}{l}\text { hábito } 1000 \text { rs; aos religiosos de acompanhar } 500 \text { rs; cova } \\
\text { 800rs; coveiro } 200 \text { rs }\end{array}$ \\
\hline sepultura para irmão & $2.400 \mathrm{rs}$ & 2.400 rs do hábito, acompanhamento, coveiro e cova \\
\hline hábito de mortalha e enterro para a mulher & $1.500 \mathrm{rs}$ & \\
\hline $\begin{array}{l}\text { pagar } 0 \text { acompanhamento aos religiosos e } \\
\text { perdoar os anuais }\end{array}$ & $2.000 \mathrm{rs}$ & 1.000 rs acompanhamento; 1.000 rs sepultura e coveiro \\
\hline hábito e sepultura para marido & $1.500 \mathrm{rs}$ & hábito e acompanhamento 1.500 rs \\
\hline hábito para o marido & $1.000 \mathrm{rs}$ & \\
\hline acompanhamento no esquife & $1.000 \mathrm{rs}$ & $\begin{array}{l}\text { pago à comunidade dos religiosos de S. Francisco da Ponte } \\
\text { pelo acompanhamento à sepultura no esquife }\end{array}$ \\
\hline mortalha & $1.480 \mathrm{rs}$ & hábito, enterro e coveiro \\
\hline
\end{tabular}

Fonte: Petições de esmola (1764-1774) 
Vejam-se alguns exemplos. O sapateiro Manuel Rodrigues, no dia 3 de março de 1768, morador na rua das Solas, freguesia Santiago, alegando o seu estado de pobreza, pediu uma esmola para o hábito e acompanhamento do funeral da mulher; o pedido foi deferido com 2.300 réis em dinheiro: 1.500 réis do hábito e acompanhamento e 800 réis da sepultura na igreja de Santiago. Maria de Santa Comba foi provida com 2.500 réis de esmola para a mortalha e sepultura de sua mãe, que morreu no Hospital Real. O dinheiro foi empregue no hábito e acompanhamento (1.500 réis), na sepultura na igreja de Santiago (800 réis) e no pagamento ao coveiro (200 réis) (1769-12-02). Em 1773, o livreiro Bernardo António, preso na cadeia do aljube por dívidas, recebeu 1.500 réis de esmola para o hábito de mortalha e enterro de sua mulher recém-falecida ${ }^{6}$.

\section{Locais de sepultura dos irmãos franciscanos seculares de Coimbra}

A fundação da ordem terceira conimbricense em 1659 exigiu, desde logo, um espaço para a realização dos atos do culto e práticas devocionais. $\mathrm{O}$ seu nascimento surgiu associado aos frades franciscanos da Ponte e, a 4 de fevereiro de 1666, sendo ministro provincial o padre mestre frei António da Nazaré, concedeu-se para capela da Ordem o altar colateral que ficava da parte do Evangelho na igreja do convento de S. Francisco da Ponte e, ainda, para cemitério dos irmãos defuntos, a metade do cruzeiro da mesma igreja correspondente ao mesmo altar (Memórias 1774-1888: 17).

"Mas o disgosto de não ter sanchristia propria" (Memórias 1774-1888: 18) levou ao pedido de mudança de capela e, em 26 de setembro de 1739, o padre provincial frei António de Santa Rosa Viterbo concede licença ao irmão Ministro e mais irmãos da Mesa da Ordem Terceira conimbricense para mudarem a capela que tinham para a capela de S. Pascoal Bailão "por n'ella lhe ficar mais comodidade para fazerem a casa do despacho que pretendem" (Barrico 1895: 23).

No ano seguinte, a 9 de março de 1740, iniciou-se a construção da capela da Ordem Terceira, anexa ao convento de S. Francisco da Ponte, cujos trabalhos terminaram 3 anos depois, e onde passaram a reunir os irmãos franciscanos seculares, capela que ainda hoje é propriedade da instituição. Contudo, vicissitudes várias levaram a sérios conflitos com os frades franciscanos, pelo que, em 1784, a Mesa da Venerável Ordem Terceira reuniu na igreja paroquial e colegiada de

6 A Ordem Terceira de Braga, no século XVIII, gastava entre 650 e 1020 réis com mortalhas (Moreaes 2009: 292). 
S. Cristóvão, uma vez que fora expulsa da Casa do Despacho e capela ereta no convento de S. Francisco da Ponte e em novembro de 1785 reuniu pela primeira vez na Sé Velha (Actas 1699-853, 229-230v), onde ficaria até 1816.

O livro com a Memória dos irmãos que faleceram neste ano de 1707 e pelos quais se celebrou na forma do Estatuto desta Venerável Ordem Terceira (1707-1748) e os livros de óbitos seguintes (1760-1774 e 1784-1797) são a principal fonte que nos permite identificar os locais de sepultura dos irmãos franciscanos seculares da cidade de Coimbra. Como já ficou referido atrás, optou-se por estudar o período durante o qual a Venerável Ordem Terceira de S. Francisco de Coimbra teve sede no burgo de Santa Clara, inicialmente no convento de S. Francisco e, depois, na sua capela da Ponte.

É feita referência que foram enterrados em caixão, por serem pobres, ou no esquife, ou levados na tumba da Misericórdia ou na tumba da irmandade de Nossa Senhora da Conceição (nos casos em que os religiosos não consentiam que fossem no seu esquife), com hábito ou amortalhados no hábito de terceiro, e ao acompanhamento, à cova e ao coveiro.

A escolha do lugar de enterramento era feita com o propósito e a crença de garantia de maior esperança na salvação da alma e "o mesmo se diga relativamente ao templo em que se desejava a última morada. Tinha-se em atenção a representação simbólica da igreja e escolhia-se aquela onde se entendia que a alma podia ser mais sufragada e receber maior apoio" (Araújo 2010: 106). Vejamos, agora, quais as igrejas que foram escolhidas para última morada dos irmãos franciscanos seculares conimbricenses.

\subsection{Sepulturas na cidade de Coimbra}

Entre 1707 e $1785^{7}$ faleceram 1.652 irmãos seculares. A memória escrita permitiu localizar 73\%, (1.211 em números absolutos), dos locais de enterramento dos irmãos franciscanos seculares (Tabela 2).

Tabela 2. Locais de sepultura dos irmãos franciscanos seculares na cidade de Coimbra

\begin{tabular}{|l|c|}
\hline \multicolumn{1}{|c|}{ Local } & No enterramentos \\
\hline Almedina & 60 \\
\hline Capela da Ordem Terceira & 12 \\
\hline Capela de Nossa Senhora da Piedade, Celas & 3 \\
\hline
\end{tabular}

Não há registos de óbitos entre 1659 e 1706, nos anos 1716, 1725 e 1726, existe um hiato temporal nos registos entre 1749 e 1759, inclusivamente, e outro entre 1775 e 1782, inclusivamente. 


\begin{tabular}{|c|c|}
\hline Local & No enterramentos \\
\hline Capela de Nossa Senhora da Vitória & 1 \\
\hline Capela do Senhor dos Remédios & 13 \\
\hline Celas & 3 \\
\hline Colégio da Graça & 1 \\
\hline Colégio de S. Bento & 6 \\
\hline Colégio de S. José dos Marianos & 7 \\
\hline Colégio de S. Pedro dos Terceiros & 44 \\
\hline Colégio de Santa Rita & 1 \\
\hline Colégio de Santo António da Estrela & 26 \\
\hline Colégio de Santo António da Pedreira & 6 \\
\hline Colégio do Carmo & 33 \\
\hline Colégio Novo & 1 \\
\hline Convento & 4 \\
\hline Convento de Celas & 1 \\
\hline Convento de Santa Ana & 21 \\
\hline Convento de Santa Clara & 18 \\
\hline Convento de Santa Teresa & 1 \\
\hline Hospital S. Lázaro & 1 \\
\hline Igreja da Companhia de Jesus & 1 \\
\hline Igreja dos Trinos & 1 \\
\hline Igreja nova & 1 \\
\hline S. Bartolomeu & 91 \\
\hline S. Bento & 2 \\
\hline S. Cristóvão & 31 \\
\hline S. Domingos & 55 \\
\hline S. Francisco da Ponte & 53 \\
\hline S. Pedro & 74 \\
\hline Salvador & 40 \\
\hline Santa Cruz & 76 \\
\hline Santa Justa & 97 \\
\hline Santiago & 197 \\
\hline Santo António dos Olivais & 8 \\
\hline Sé & 48 \\
\hline Senhor Jesus do Rosário & 8 \\
\hline
\end{tabular}

Fonte: Registos de óbitos dos irmãos, 1707-1785 
As igrejas colegiadas de Santiago (197) [16\%] e de S. Bartolomeu (91) [7,5\%] e a igreja de Santa Justa (97) [8\%] são aquelas que congregam o maior número de enterramentos. Relativamente às duas primeiras igrejas, não será de estranhar pela proximidade geográfica visto que a Ordem Terceira de Coimbra esteve sedeada no convento de S. Francisco desde a sua origem ( 5 de janeiro de 1659) até 1743 (data de conclusão da construção da Capela da Ponte, edifício autónomo, mas anexo ao dito convento), e de onde só sai em 1785 por cisão com os frades franciscanos.

É necessário ter em conta que o costume na Época Moderna era os irmãos serem sepultados na igreja da sua freguesia de residência, e o facto de existir grande número de enterramentos na igreja de Santa Justa demonstra que a ordem terceira de Coimbra tinha membros dispersos por toda a malha urbana da cidade. De facto, com maior ou menor número de casos, encontram-se irmãos franciscanos seculares sepultados em igrejas paroquiais, igrejas de colégios e conventos tanto na Alta como na Baixa da cidade.

De salientar, também, que os enterramentos na igreja do mosteiro de Santa Cruz (76), na igreja de S. Pedro (74), na igreja de S. João de Almedina (60) e na igreja do convento de S. Domingos (55) registam maior número que os sepultamentos no convento de S. Francisco da Ponte (53). Uma nota também para os enterramentos no colégio do Carmo (33) porque, na sequência da extinção das ordens religiosas masculinas, em 1834, o Conselho da Venerável Ordem obteve do poder régio a igreja do Carmo, sita na rua da Sofia, em 1837, e o restante edifício do extinto colégio dos Carmelitas Calçados, em 1841, para aí se estabelecer e fundar o seu hospital, local que é ainda hoje a sede da instituição.

No entanto, e se "todos os Irmãos tinham garantido o enterro nos jazigos da ordem" (Lopes 2010: 111), ou, como estipulavam os estatutos de 1697 da Ordem Terceira do Carmo do Rio de Janeiro, se "todo o Irmão que falecer e quiser ser enterrado nos jazigos da Ordem, se lhe dará neles sepultura na parte onde houver lugar" (Martins 2009: 387-388), aquilo que se constata relativamente à Ordem Terceira de Coimbra é que a sua capela, (quer fosse a primitiva no convento de S. Francisco, referida como "nossa capela velha", quer fosse a nova capela da Ponte, anexa ao respetivo convento, designada como a "nossa capela"), não colheu a preferência: conta apenas com 12 enterramentos, embora não tenhamos indicação do sepultamento de $27 \%$ dos irmãos seculares ${ }^{8}$. A justificação para o reduzido número de sepultamen-

8 Inversamente, os franciscanos seculares de Braga escolheram a igreja da Ordem como principal local de enterramento entre 1718-1822 (Moraes 2009: 299). 
tos nas capelas da Ordem Terceira de Coimbra pode estar nos Estatutos de 1709:

E por este mesmo mandamos o estatuto em que se ordena que na nossa capella attendendo az pouquas sepulturas que tem se não emterem sinão aquelles irmãos que na Meza tiverem servido ao menos duas vezes aos quais he justo pague a Ordem na morte o zello com que serviram em vida, e se alguma outra pessoa filha desta mesma Ordem sem o requezito assima por sua devoção se quizer emterrar na dita capella se lhe não dará nella sepultura por menos esmola de dez mil reis (Óbitos 1709, fl. 2-2v).

Sabe-se, por exemplo, que Dona Teresa Josefa Ferreira, falecida a 7 de julho de 1741 foi enterrada na capela velha; que o cónego António Fernandes Velho, que foi ministro da Ordem Terceira de Coimbra entre 1720 e 1722, faleceu a 13 de janeiro de 1742 e foi sepultado na "nossa capela velha"; que o ferreiro João de Sousa, morador na rua da Ponte, subúrbio Santa Clara, foi a sepultar no esquife da Ordem "à nossa capela na sepultura debaixo do púlpito junto a porta" em 19 de fevereiro de 1748; e que o licenciado Luís de Oliveira (ministro em 1735-1736 e 1753), faleceu no dia 30 de março de 1762 e foi sepultado na capela da Ordem.

Complementarmente a estes exemplos, na série de Testamentos localizam-se três documentos de irmãos seculares cuja última vontade foi serem enterrados na capela da Ordem: dona Catarina Maria Antónia da Silva moradora na Orvieira, mulher de José Pessoa de Almeida de Sá, deixa escrito que quer ser sepultada na capela da Ordem Terceira no convento de S. Francisco da Ponte e amortalhada no hábito de S. Francisco, com o acompanhamento dos religiosos (Testamentos, 28-06-1716); Margarida Monteira, viúva de Manuel Fernandes, mestre de obras do Real Mosteiro de Santa Clara, queria ser enterrada com o hábito de S. Francisco e sepultada na capela da Ordem, junto à sepultura de seu marido (do lado de dentro das grades) "para o que dá a esmola costumada” (Testamentos, 05-08-1716); e João da Silva Caturro, advogado, queria ser enterrado com o hábito de S. Francisco e levado no esquife da Ordem à sepultura "que será na capela da mesma Ordem" (Testamentos, 06-06-1764). A escolha da mortalha visava congregar maiores benefícios para a alma, "moda" que se generalizou e que era parte integrante da economia da salvação (Araújo 1995: 15), ao mesmo tempo "A imposição do uso do hábito revela o desejo dos irmãos em demonstrar perante a comunidade a pertença ao sodalício pelo defunto" (Moraes 2009: 289). As vontades das testadoras Catarina Maria Antónia da Silva e Margarida Monteiro foram cumpridas, os seus nomes aparecem nos registos de óbitos como tendo sido 
sepultadas na capela da Ordem; quanto ao último, o seu nome não aparece nos registos, não sabemos o que lhe aconteceu.

Os enterramentos eram feitos dentro das igrejas, em capelas (por exemplo, na igreja de Santiago, foram enterrados 6 irmãos na capela dos ourives; e 2 irmãos foram sepultados na capela da Senhora da Piedade, em Celas) ou fora, nos claustros (por exemplo: Luzia de S. José, moça do mosteiro de Santa Clara foi sepultada nos claustros do referido mosteiro, onde faleceu a 25 de setembro de 1747; e Micaela Francisca, mulher de João Gomes Barreteiro, moradora aos degraus de Quebra Costas, foi enterrada "aos claustros da Sé", a 4 de abril de 1763).

De facto, a riqueza informacional dos registos de óbitos dos irmãos está patente na precisão de indicação de alguns locais de sepultura, como se pode verificar pelos exemplos seguintes. Do padre Manuel de Oliveira, morador na rua Corpo de Deus, é dito que foi a sepultar na tumba dos clérigos à igreja de Santiago na sepultura n. ${ }^{\circ}$ 20, a 5 de outubro de 1747; Arcângela Maria, viúva, moradora na Calçada, foi a sepultar "no nosso esquife" à igreja de S. Bartolomeu na sepultura n. ${ }^{\circ}$ 14, em 23 de outubro de 1747; o boticário Francisco Cardoso de Assunção, morador na Calçada, foi a sepultar "no nosso esquife" à igreja de Santiago, em 31 de outubro de 1747, e foi sepultado ao pé da porta do claustro "mas a dita sepultura não tem número"; Manuel Lopes Teixeira, prior de S. Bartolomeu, morador na rua de João Cabreira, foi a sepultar na tumba dos clérigos a igreja de S. Bartolomeu na sepultura n. 3 (1747); a viúva Joana Correia, que morava no Adro de Baixo da freguesia de S. Bartolomeu foi a sepultar à igreja da sua freguesia na sepultura n. ${ }^{\circ} 10$, no dia 9 de dezembro de 1747; e Maria do Salvador, solteira, moradora na rua dos Gatos, em 19 de fevereiro de 1748, teve a última morada na sepultura n. ${ }^{\circ} 17$ da igreja de S. Bartolomeu. Estes exemplos são inequívocos nas coordenadas exatas que permitem, hoje, identificar as ossadas (caso ainda existam) nestas sepulturas dentro do corpo da igreja. Curiosamente, estes exemplos repartem-se entre a igreja de Santiago (2) e a igreja de S. Bartolomeu (3).

Outros assentos de óbitos contêm indicações precisas do local de enterramento. Ângela da Conceição, natural da freguesia de Santa Justa, foi sepultada na capela da Senhora da Piedade de Celas porque assistia em Mainça (faleceu no dia 24 de julho de 1739); Josefa do Espírito Santo, viúva, moradora na rua dos Sapateiros, "foi no nosso esquife a sepultar na igreja do convento de S. Domingos nas sepulturas da Irmandade de Nossa Senhora do Rosário, em 26 de Mayo de 1747”; Manuel Machado Lopes, sapateiro, morador junto à capela da Ordem Terceira em Santa Clara, "foi no nosso esquife a sepultar na igreja do convento de S. Francisco da Ponte na sepultura da Irmandade 
de Nossa Senhora da Conceição, em 6 Junho de 1747”; Domingos de Oliveira, pintor de louça, rua de Tingerodilhas, freguesia de Santa Cruz, "foi no nosso esquife a sepultar a igreja do convento de S. Domingos nas sepulturas da Irmandade do Senhor Jesus, em 8 de julho de 1747”; Dionísio de Macedo Varela, escrivão da correição, morador ao fundo da Praça, freguesia de Santiago, faleceu na igreja de S. João de Santa Cruz, "foi a sepultar no nosso esquife a igreja do convento de S. Francisco da Ponte em 23 agosto 1747”; A viúva Isabel de Macedo, moradora ao Cimo da Praça, foi a sepultar à igreja de Santiago no arco cruzeiro, no dia 9 de dezembro de 1747; Bernardo João Xavier Monteiro, que faleceu no $1^{\circ}$ de dezembro de 1762 , foi a sepultar na igreja da Companhia de Jesus, onde era administrador.

Se a grande maioria ficava sepultada na freguesia de residência, outros havia que percorreram largo caminho até chegar à sua última morada. O escrivão da correição, Dionísio de Macedo Varela, morador ao fundo da Praça, faleceu na igreja de S. João de Santa Cruz, e "foi a sepultar no nosso esquife a igreja do convento de S. Francisco da Ponte em 23 agosto 1747”; o prior de Vila Nova de Anços, Carlos Gomes da Silva, faleceu na quinta das Canas e foi levado "no nosso esquife desde a rua das Parreiras até o convento de S. Francisco da Ponte” (1764-1765); José António, livreiro, da freguesia de S. Cristóvão, faleceu no lugar da Portela "donde veio na tumba de S. Sebastião das Torres athe o Arco da Estrella e dahi pera a sua freguesia no esquife em 4 de Setembro de 1773"; o doutor Joaquim Diogo da Mota e Silva, também falecido na Quinta das Canas, no dia 10 de junho de 1772 foi "de noute em andas ao colégio de S. Bento".

Do que fica atrás exposto, conclui-se que, nos enterramentos na cidade de Coimbra, as 9 igrejas paroquiais (que eram simultaneamente colegiadas ou capitulares) de S. Pedro, S. João de Almedina, S. Salvador, Sé e de S. Cristóvão (na Alta) e de S. Bartolomeu, S. Tiago, S. João de Santa Cruz e Santa Justa (na Baixa) congregam, em conjunto, 66,81\% dos locais de enterramento dos irmãos franciscanos seculares. Por seu lado, os conventos são última morada apenas de 4,1\% da população estudada. Situação inversa acontece em Lisboa onde "As igrejas paroquiais, embora controlem o movimento de falecimentos, não apresentam, num primeiro momento, uma vantagem folgada sobre os conventos. A mancha de sepulturas conventuais é muito elevada até 1770" (Araújo 1995: 10). Esta diferença talvez se explica, em parte, pela existência de inúmeros colégios universitários (seculares e religiosos) implantados na cidade de Coimbra desde a fixação do Estudo Geral definitivamente na cidade em 1537, e onde forma enterrados $11,36 \%$ dos irmãos franciscanos seculares, colégios que surgem como concorrentes dos conventos na escolha para última morada. 


\subsection{Sepulturas fora da cidade de Coimbra}

Os livros de óbitos também fornecem indicações sobre as irmãs e irmãos que foram sepultados fora da cidade de Coimbra, por terem falecido noutras localidades (ver Tabela 3), como os exemplos de Maria Pereira, que morreu em 1728 na vila de Montemor e aí foi sepultada; Francisco Manuel de Sousa, feitor das religiosas de Santa Ana, faleceu em outubro de 1732 na vila de Botão, em cuja igreja foi sepultado; o reverendo Bernardo Nicolau da Costa "estando em Carvalho" foi sepultado na igreja da vila de Carvalho, mesmo sendo residente na freguesia de Santa Justa, em Coimbra (1704-04-02); João Lobo Leitão "faleceu na sua terra que dizem é Oliveira do Conde"; o barbeiro António do Sacramento, morador na rua das Parreiras, subúrbio Santa Clara, faleceu em 22 de junho de 1747 no Hospital de Todos os Santos, em Lisboa, e "como me constou por certidão de Diogo Correia da Mota escrivão do dito hospital e consta do livro dos assentos da enfermaria de S. João de Deus de 1747”, sem indicação do local de enterramento. O exemplo de José António de Matos de quem "houve noticia que falecera em Alcobaça no mês de fevereiro de 1759"; o ourives João de Oliveira que faleceu no dia 7 de junho de 1761 em Góis "onde foi sepultado"; o sapateiro, António Teixeira, residente em S. Martinho do Bispo, faleceu em Lisboa "em dia de Todos os Santos o primeiro de Novembro de 1755 e ainda agora se soube teve as suas missas" (ficou registado no ano 1771-1772); e Benta Maria Joaquina, que faleceu na Nazaré, patriarcado de Lisboa, enterrou-se na capela de Nossa Senhora dos Anjos da vila da Pederneira (1773-1774).

Não se deixavam se cumprir os sufrágios pelos irmãos que faleciam, ainda que morressem fora da cidade de Coimbra, assim que disso tivessem notícia; a única condição era terem pago a esmola dos anuais.

Tabela 3. Locais de sepultura dos irmãos franciscanos seculares fora da cidade de Coimbra

\begin{tabular}{|c|c|c|c|}
\hline Local & No enterramentos & Local & No enterramentos \\
\hline Aguada & 1 & Góis & 1 \\
\hline Águeda & 1 & Guarda & 1 \\
\hline Alcobaça & 1 & Lamarosa & 1 \\
\hline Almalaguês & 1 & Lavares & 1 \\
\hline Almeida & 1 & Leiria & 2 \\
\hline Ançã & 2 & Lisboa & 14 \\
\hline Angra, Açores & 1 & Lorvão & 1 \\
\hline Antanhol & 2 & Louriçal & 1 \\
\hline Antuzede & 2 & Lousã & 1 \\
\hline
\end{tabular}




\begin{tabular}{|c|c|c|c|}
\hline Local & No enterramentos & Local & No enterramentos \\
\hline Arazede & 1 & Mangualde & 1 \\
\hline Assafarge & 4 & Miranda & 3 \\
\hline Aveiro & 3 & Montemor-o-Velho & 2 \\
\hline Avelãs & 1 & Oliveira do Conde & 2 \\
\hline Avenal & 1 & Palheira & 1 \\
\hline Baía, Brasil & 1 & Penacova & 2 \\
\hline Barcouço & 1 & Pereira & 1 \\
\hline Bera & 3 & Pombal & 1 \\
\hline Bissau & 1 & Pombeiro & 2 \\
\hline Botão & 1 & Redinha & 1 \\
\hline Braga & 2 & Ribeira de Bera & 1 \\
\hline Caldas & 1 & Ribeira de Frades & 5 \\
\hline $\begin{array}{l}\text { Capela de Nossa Senhora } \\
\text { dos Anjos da vila da } \\
\text { Pederneira, Nazaré }\end{array}$ & 1 & Ribeira do Campo & 1 \\
\hline Capela particular & 3 & S. João do Bispo & 4 \\
\hline Carvalho & 1 & S. Martinho do Bispo & 25 \\
\hline Casal Comba & 1 & Santa Comba Dão & 1 \\
\hline Castelo Viegas & 6 & Santo Varão & 1 \\
\hline Ceira & 1 & Sebal & 3 \\
\hline Cernache & 2 & Seia & 1 \\
\hline Condeixa & 9 & Semide & 2 \\
\hline $\begin{array}{l}\text { Convento dos Capuchos } \\
\text { dos Olivais }\end{array}$ & 1 & Souselas & 1 \\
\hline Couço & 1 & Taveiro & 2 \\
\hline Couto do Mosteiro & 1 & Terra da Feira & 1 \\
\hline Esgueira & 1 & Tondela & 2 \\
\hline Évora & 1 & Torres do Mondego & 3 \\
\hline Fala & 1 & Trouxemil & 1 \\
\hline Fora da cidade & 1 & Vila Nova de Monsarros & 2 \\
\hline Fornos & 1 & Vila Nova do Casal & 1 \\
\hline
\end{tabular}

Fonte: Registos de óbitos dos irmãos, 1707-1785

Aparecem também outros registos menos precisos, aqueles de que apenas "houve notícia" que morreram, que "faleceu fora da terra" (Mónica da Cruz, 1730) sem mais qualquer indicação, ou que "veio notícia que faleceu" Agostinho Barbosa em S. Salvador da Baía, Brasil (1743-1744). 


\section{Conclusão}

A Venerável Ordem Terceira da Penitência de S. Francisco de Coimbra não deixou de garantir aos seus membros o acompanhamento dos defuntos à sepultura e os sufrágios por alma dos irmãos falecidos. Os registos de óbito dos irmãos terceiros seculares são fonte primordial para conhecer o seu local de sepultura. A partir das fontes sabe-se que foram enterrados maioritariamente nas igrejas paroquiais da cidade de Coimbra; no entanto, também são referenciados como local de sepultura, as igrejas de colégios e conventos da cidade, o que confirma que a Ordem Terceira de S. Francisco tinha ampla implantação na malha urbana de Coimbra.

Se "a transposição do muro da igreja ficava apenas reservada aos poderosos. Respeitando esta hierarquia, «a função cemiterial começava no interior da igreja, dentro dos seus muros, e continuava para além dela», no recinto envolvente" (Araújo 1995: 2) nos pátios e nos adros, por exemplo, aquilo que se verifica é que os irmãos franciscanos seculares garantiam um lugar no solo sagrado das igrejas paroquias, colegiadas, de conventos e colégios. Mas se "o critério de valorização do espaço funerário varia com a proximidade do altar-mor, coro e capelas colaterais, por esta ordem” (Araújo 1995: 7), e se a maioria dos enterramentos dos irmãos franciscanos seculares é feita nas igrejas paroquias, de colégios e conventos, então, não encontramos tanto neste registo os fundadores, padroeiros, benfeitores e beneficiados, a quem estavam reservados, certamente, os primeiros sítios, nem os dos pobres, a quem estavam reservados os espaços fora das paredes, o que significa que a composição dos irmãos franciscanos seculares se situava entre estes dois mundos.

\section{Bibliografia}

\section{Fontes}

Arquivo da Venerável Ordem Terceira da Penitência de S. Francisco de Coimbra (AVOTFC)

Estatutos da Nossa Ordem, vários termos da Mesa e Juntas Gerais, entradas e profissões e modo das figuras e procissões (1659-01-05 a 1739-03-28).

Livro dos termos e resoluções da Ordem Terceira (liv. A2, 1724-06-27 a 1845-09-29)

Livro de Memórias da Nossa Venerável Ordem feito em 1774 (liv. A4, 1774-03-08 a 188805-10)

Actas e Eleições (liv. E2, 1699-01-21 a 1853-06-05) 
Registos de óbitos dos irmãos (liv. D1, 1709-12-31 a 1728-10-28 / 1712-01-10 a 1718-02-20 / 1707-1748)

Registos de óbitos dos irmãos (liv. D2, 1760-11-12 a 1774-05-17)

Registos de óbitos dos irmãos (liv. D3, 1784-04-06 a 1797-06-10)

Petições de esmolas (1721-1785).

\section{Estudos}

ARAÚJO, Ana Cristina Cardoso dos Santos Bartolomeu de (1995). A morte em Lisboa: atitudes e representações: 1700-1830. Tese de doutoramento em Letras (História Moderna e Contemporânea) apresentada à Faculdade de Letras da Universidade de Coimbra (https://estudogeral.sib.uc.pt/handle/10316/689, consultado em 2016.04.01).

ARAÚJO, Maria Marta Lobo de (2010). "O mundo dos mortos no quotidiano dos vivos: celebrar a morte nas Misericórdias portuguesas da época moderna”. Comunicação \& Cultura, 10, 101-114.

ARAÚJO, Maria Marta Lobo de (2004). "Vestidos de cinzento os irmãos terceiros franciscanos de Vila Viçosa através dos estatutos de 1686”, Callipole, 12, 47-60.

BARRICO, Joaquim Simões (1895). Notícia Histórica da Venerável Ordem Terceira da Penitência de S. Francisco da Cidade de Coimbra. Coimbra: Typographia de J. J. Reis Leitão.

CATROGA, Fernando (1993). "Morte romântica e religiosidade cívica”, in José Mattoso (dir.), História de Portugal. Vol. 5. Lisboa: Círculo de Leitores, 595-607.

GOUVEIA, António Camões... [et al.] (2000), Humanismos e reformas. In Carlos Moreira Azevedo (dir.), História religiosa de Portugal. Vol. 2. Lisboa: Círculo de Leitores.

LOPES, Maria Antónia (2010). Protecção social em Portugal na Idade Moderna. Coimbra: Imprensa da Universidade.

LOPES, Maria Antónia (2000). Pobreza, assistência e controlo social. Coimbra (17501850). Vol. 2. Viseu: Palimage Editores.

MARTINS, William de Souza (2009). Membros do Corpo Místico, Ordens Terceiras no Rio de Janeiro (c. 1700-1822). São Paulo: Editora da Universidade de S. Paulo.

MORAES, Juliana de Mello (2009). Viver em penitência: os irmãos terceiros franciscanos e as suas associações, Braga e São Paulo (1672-1822). Tese de doutoramento em História (ramo do conhecimento em Idade Moderna e Contemporânea), Instituto de Ciências Sociais - Universidade do Minho (http://hdl.handle.net/1822/10870, consultado em 2016.04.01).

SÁ, Isabel dos Guimarães \& Lopes, Maria Antónia (2008). História breve das misericórdias portuguesas (1498-2000). Coimbra: Imprensa da Universidade.

SILVA, Ana Margarida Dias da (2013). Inventário do Arquivo da Venerável Ordem Terceira da Penitência de S. Francisco da Cidade de Coimbra (1659-2008). Lisboa: CEHR-UCP (http://repositorio.ucp.pt/bitstream/10400.14/10334/4/IDDs2InventarioOrdemTerceira.pdf, consultado em 2016.04.01). 